九州大学学術情報リポジトリ

Kyushu University Institutional Repository

\title{
Development of a Quality Certification and Maturity Classification Method for Liquid Fertilizer by Measuring the Electrical Conductivity (EC) of Swine Manure
}

Halder, Joshua Nizel

Laboratory of Environmental Economics, Department of Agricultural and Resource Economics, Faculty of Agriculture, Kyushu University | Department of Environmental Engineering, Sangji University

\section{Kang, Taek-Won}

Laboratory of Environmental Economics, Department of Agricultural and Resource Economics, Faculty of Agriculture, Kyushu University | Department of Environmental Engineering, Sangji University

Yabe, Mitsuyasu

Laboratory of Environmental Economics, Department of Agricultural and Resource Economics, Faculty of Agriculture, Kyushu University

Lee, Myung-Gyu

Laboratory of Environmental Economics, Department of Agricultural and Resource Economics, Faculty of Agriculture, Kyushu University | Department of Environmental Engineering, Sangji University

https://doi.org/10.5109/1801784

出版情報：九州大学大学院農学研究院紀要. 62 (1)，pp. 205-212，2017-02-24. Faculty of Agriculture, Kyushu University

バージョン：

権利関係: 


\title{
Development of a Quality Certification and Maturity Classification Method for Liquid Fertilizer by Measuring the Electrical Conductivity (EC) of Swine Manure
}

\author{
Joshua Nizel HALDER ${ }^{1}$, Taek-Won KANG ${ }^{1}$, Mitsuyasu YABE and Myung-Gyu LEE ${ }^{1 *}$ \\ Laboratory of Environmental Economics, Department of Agricultural and Resource Economics, \\ Faculty of Agriculture, Kyushu University, Fukuoka 812-8581, Japan \\ (Received October 20, 2016 and accepted November 4, 2016)

\begin{abstract}
The increasing need for liquid fertilizers along with the high production and treatment rate of swine manure pose a great concern in regard to the quality control and certification of fertilizers rapidly produced. In this study, 66 liquid manure samples were collected from national livestock manure co-recycling centers. These 66 samples were tested and classified into three categories based on Liquid Fertilizer Germination Index (LFGI). In addition, the physiochemical parameters of manure specimens were tested, including $\mathrm{pH}$, $\mathrm{NaCl}$, total sulfur (TS), total nitrogen (TN), ammonium-nitrogen $\left(\mathrm{NH}_{4}-\mathrm{N}\right)$, nitrate-nitrogen $\left(\mathrm{NO}_{3}-\mathrm{N}\right)$, total phosphorus (TP), potassium (K), and electrical conductivity (EC). EC had a positive correlation with TN (0.879), $\mathrm{NH}_{4}-\mathrm{N}(0.816), \mathrm{K}(0.693)$, and $\mathrm{NaCl}(0.625)$ with a significance of $\mathrm{p}<0.01$ but a negative correlation with LFGI (-0.719). This study demonstrated that EC could be used as an indicator in rapid testing methods for quality control to certify the maturity level of liquid manure fertilizers.
\end{abstract}

Key words: EC, liquid fertilizers, manure maturity, nutrients, quality control, swine manure

\section{INTRODUCTION}

Manure is an organic fertilizer and a valuable source of nutrients for crops to improve soil efficiency for crop production (Lorimor, 2004). If produced swain manure contain $4 \%$ of solid materials, may define as liquid manure (Lorimor, 2004). The properties and quality of manure fertilizers depend on various factors that may affect the nutrient quality of the final products. Swine manure contains huge amounts of both nutrients (macro and micro) and pollutants (heavy metals and pathogens) (Tam and Vrijmoed, 1990, 1993; Castillón, 1993; Araji et al., 2001; Baloda et al., 2001). These components are mostly found in an inorganic soluble form that is easy to uptake, but the amount of available nutrients are less than in composted fertilizers; thus, liquid manure fertilizers need to be applied in a huge volume for effective results (Kim et al., 2013). However, uncontrolled application of these soluble inorganic nutrients as well as improperly treated manure application may cause serious soil and groundwater pollution and crop loss because of the presence of phytotoxic compounds (Alburquerque et al., 2006; Butler et al., 2001; Moore et al., 2009; Chen et al., 2007). This frequently happens when ions from the nutrient, such as nitrate and phosphorus, leach into rainwater and become stagnant underground (Márquez-Molina et al., 2014).

According to a report by Kim (2014), 5.1 L/head of swine manure is produced every day, and 11,04 $\mathrm{m}^{3} /$ day of manure is recycled in public manure treatment centers in the Republic of Korea. Since manures that are used in fields have high levels of organic matter and growth of

\footnotetext{
${ }^{1}$ Department of Environmental Engineering, Sangji University, Wonju 220-702, South Korea

* Corresponding author: Myung-Gyu LEE (E-mail: mglee@ sangji.ac.kr)
}

agricultural practices requires increasing amounts of fertilizers, unknown fertilizer quality may cause environmental problems (Zaha et al., 2013; European Environmental Agency, 2000). Certain key manure characteristics can be used to certify the quality of the manure to minimize nutrient loss (Suresh et al., 2009), improve effectiveness (Tunney and Molly 1975), and increase the rate of application; however, excess use may cause water and soil pollution (Sures et al., 2009; Provolo and Martinez-Suller, 2005). Therefore, maximal use of manure fertilizers should be optimized in an economically and environmentally friendly way.

Nowadays, most manure analyses are performed following various conventional chemical testing procedures. These procedures are time-consuming and costly. Occasionally, multiple chemical tests may conflict with each other; this leads to difficulty in determining the quality of fertilizers. On the other hand, certain rapid testing techniques are widely available; however, these techniques also face some challenges relating the presentation of samples and manure sampling (Xing, 2007). Nevertheless, some notable studies have been performed using manure sampling procedures based on total nitrogen (TN) and total phosphorus (TP) (Zhu et al., 2004; 2003; Ndegwa and Zhu, 2003). The relationship between electrical conductivity (EC) and nutrient contents (TN, TP, and K) can be easily determined; thus, EC could be used to estimate fertilizer quality, as indicated by Martı́nez-Suller et al. (2008). In a study by Stevens et al. (1995), there is a distinct correlation between EC and ammonium-nitrogen $\left(\mathrm{NH}_{4}-\mathrm{N}\right)$ and $\mathrm{K}$ in pig and cattle slurry. Another study by Moral et al. (2005) showed that P is more closely correlated with solid-related parameters but has a weak and undefined correlation with EC; this was supported by Martı́nezSuller et al. (2008) and Suresh et al. (2014). Nevertheless, the above-mentioned authors demon- 
strated in their study that EC could easily determine fertilizer value as well as quality.

EC is a measurement of the dissolved material in an aqueous solution, which relates to the ability of the material to conduct electrical current through it. The higher the dissolved material in a water or soil sample, the higher the EC will be in that material. In manure, EC reflects the degree salinity in relation to the easily decomposable compositions of manure during treatment period by assessing the total soluble ions that may or may not affect its quality as a fertilizer (Fernández et al., 2007; Cardenas and Wang, 1980; Moore et al., 2009; Saviozzi et al., 1987). On the other hand, GI (germination index) is used to evaluate manure phytotoxicity and stability. GI is very sensitive to the nutrient contents and toxic elements of a fertilizer and defines the maturity of the manure (Oleszczuk, 2008; Zaha et al., 2013). In our previous study on LFGI or Liquid Fertilizer Germination Index (Joshua et al., 2016), we demonstrated a unique germination index method only for liquid manure fertilizers. During the study, we also found that EC is closely related to GI and other physiochemical properties of the specimens evaluated, and EC may be used as a quality certification tool to assess the solid compost and slurry type fertilizers in the above-men- tioned studies. In addition, EC testing is a rapid and convenient test these days; thus, it could be applied onsite in a quality check technology to define the maturity of liquid manure fertilizers.

The main goal of this study was to establish EC as a regulatory indicator of quality in rapid test technologies for liquid manure fertilizers by evaluating its relationship with LFGI and other fertilizer properties in 66 liquid manure fertilizer specimens.

\section{MATERIALS AND METHODS}

\section{Materials and storage}

A total of 66 manure samples were collected from national livestock manure co-recycling centers and manure distribution centers across South Korea. The amount of manure collected was $500 \mathrm{~mL}$ for each specimen in a sterile plastic container. During the study period, the specimens were stored at $4^{\circ} \mathrm{C}$ until completion of all experiments.

\section{Physiochemical analysis}

Physiochemical analyses of $\mathrm{pH}, \mathrm{EC}, \mathrm{NaCl}, \mathrm{TN}, \mathrm{NH}_{4}-\mathrm{N}$, nitrate-nitrogen $\left(\mathrm{NO}_{3}-\mathrm{N}\right)$, organic nitrogen (Org-N), TP, $\mathrm{K}$, and total sulfur (TS) in the samples were performed.

Table 1. Classification of 66 specimens based on Liquid Fertilizer Germination Index (LFGI)

\begin{tabular}{|c|c|c|c|c|c|c|c|}
\hline Sample No. & LFGI & Sample No. & LFGI & Sample No. & LFGI & Sample No. & LFGI \\
\hline 1 & 96.03 & 23 & 0.00 & 45 & 0.00 & 48 & 0.00 \\
\hline 2 & 89.65 & 24 & 0.1209 & 46 & 54.85 & 49 & 0.00 \\
\hline 3 & 0.00 & 25 & 0.00 & 47 & 0.00 & 50 & 0.00 \\
\hline 4 & 121.19 & 26 & 0.1017 & mean & 25 & 51 & 0.00 \\
\hline 5 & 109.31 & 27 & 102.67 & & & 52 & 0.65 \\
\hline 6 & 85.50 & 28 & 118.05 & & & 53 & 0.09 \\
\hline 7 & 90.41 & 29 & 0.00 & & & 54 & 0.00 \\
\hline 8 & 90.12 & 30 & 0.00 & & & 55 & 102.52 \\
\hline 9 & 77.87 & 31 & 0.03 & & & 56 & 0.10 \\
\hline 10 & 91.52 & 32 & 24.61 & & & 57 & 0.01 \\
\hline 11 & 79.86 & 33 & 0.00 & & & 58 & 0.00 \\
\hline 12 & 102.32 & 34 & 9.38 & & & 59 & 0.00 \\
\hline 13 & 80.67 & 35 & 28.75 & & & 60 & 0.00 \\
\hline 14 & 87.92 & 36 & 9.51 & & & 61 & 0.15 \\
\hline 15 & 98.29 & 37 & 64.25 & & & 62 & 0.09 \\
\hline 16 & 100.29 & 38 & 14.90 & & & 63 & 0.00 \\
\hline 17 & 85.25 & 39 & 0.50 & & & 64 & 0.03 \\
\hline 18 & 108.12 & 40 & 0.14 & & & 65 & 0.02 \\
\hline 19 & 117.44 & 41 & 0.00 & & & 66 & 0.06 \\
\hline 20 & 79.30 & 42 & 0.01 & & & mean & 5 \\
\hline 21 & 91.42 & 43 & 93.42 & & & & \\
\hline 22 & 96.31 & 44 & 92.33 & & & & \\
\hline mean & 90 & & & & & & \\
\hline
\end{tabular}

No. $1-22(22)=$ matured

No. $23-47(25)=$ semi-matured

No. 48-66 (19) = immature 
Maturity was determined by GI. In addition, $\mathrm{pH}$ and EC were measured using an YSI-556MPS (xylem Inc. USA) handheld meter. $\mathrm{NaCl}$ was measured by the silver nitrate titration method and by the ion-electron method after LFGI treatment. TP was determined by the ascorbic acid method (APHA, 2005). TN, NH4-N, and NO3-N were analyzed by the Kjeldahl method followed by standard sewage analysis methods (JSWA, 1984). GI was determined by the LFGI method.

\section{Statistical analysis}

For data analysis, basic statistical analyses were performed to determine the maximum, minimum, mean, and standard deviation values of the fertilizer elements. SPSS software was used to determine the relationship of EC with these fertilizer elements, and we used Microsoft Office Excel 2013 for graphical purposes. However, Pearson's correlation coefficient was also used to determine the relevant relationship between EC and other physiochemical parameters as well as to demonstrate the similarity between EC and LFGI.

Table 2. Individual electrical conductivity (EC) values of 66 specimens at different maturity stages

\begin{tabular}{|c|c|c|c|c|c|}
\hline No. & $\mathrm{EC}(\mathrm{mS} / \mathrm{cm})$ & No. & $\mathrm{EC}(\mathrm{mS} / \mathrm{cm})$ & No. & $\mathrm{EC}(\mathrm{mS} / \mathrm{cm})$ \\
\hline 1 & 11.41 & 1 & 27.18 & 1 & 19.34 \\
\hline 2 & 8.90 & 2 & 12.36 & 2 & 38.60 \\
\hline 3 & 23.86 & 3 & 22.74 & 3 & 21.94 \\
\hline 4 & 7.03 & 4 & 14.89 & 4 & 22.12 \\
\hline 5 & 8.45 & 5 & 5.52 & 5 & 22.31 \\
\hline 6 & 9.49 & 6 & 11.06 & 6 & 17.08 \\
\hline 7 & 5.28 & 7 & 19.66 & 7 & 20.02 \\
\hline 8 & 9.25 & 8 & 29.06 & 8 & 11.86 \\
\hline 9 & 6.41 & 9 & 23.91 & 9 & 39.70 \\
\hline 10 & 8.77 & 10 & 14.22 & 10 & 28.10 \\
\hline 11 & 14.77 & 11 & 29.84 & 11 & 29.46 \\
\hline 12 & 5.88 & 12 & 18.67 & 12 & 17.56 \\
\hline 13 & 4.10 & 13 & 29.07 & 13 & 32.60 \\
\hline 14 & 7.11 & 14 & 18.93 & 14 & 24.71 \\
\hline 15 & 6.16 & 15 & 12.70 & 15 & 11.74 \\
\hline 16 & 7.31 & 16 & 16.94 & 16 & 19.86 \\
\hline 17 & 6.89 & 17 & 25.50 & 17 & 18.83 \\
\hline 18 & 5.04 & 18 & 26.63 & 18 & 29.85 \\
\hline 19 & 8.75 & 19 & 31.00 & 19 & 12.97 \\
\hline 20 & 20.99 & 20 & 23.68 & mean & 23.09 \\
\hline 21 & 20.91 & 21 & 13.01 & & \\
\hline 22 & 13.71 & 22 & 17.81 & & \\
\hline \multirow[t]{4}{*}{ mean } & 10.02 & 23 & 20.18 & & \\
\hline & & 24 & 9.24 & & \\
\hline & & 25 & 21.06 & & \\
\hline & & mean & 19.79 & & \\
\hline
\end{tabular}

No. $1-22(22)=$ matured

No. 23-47 (25) = semi-matured

No. 48-66 (19) = immature

\section{RESULTS AND DISCUSSION}

\section{Determination of the maturity level of liquid manure specimens by LFGI}

As described in our study on LFGI (Joshua et al., 2016), we determined the maturity of 66 samples using LFGI. The samples were classified as matured (22 samples) with an average LFGI of 90, semi-matured (25 samples) with an average LFGI of 25, and immature (19 samples) with an average LFGI of 9 , as shown in Table 1 and Fig. 2(A).

\section{Relationship between EC and LFGI}

Table 1 and Table 2 show the LFGI and EC of samples at different stages. Specimens with a high LFGI had a low EC value, and those with a high EC value had a low LFGI. Seed germination is highly correlated with salt stress (Joshua, 2016), and the high phytotoxicity level of manure is caused by the slow breakdown of mineral salts (Zaha, 2013). Therefore, EC and LFGI had a negative correlation as shown in Fig. 1, Fig. 2, and Table 4. Fig. 1 shows that when EC was decreased, LFGI was increased. The lowest EC value $(4.1 \mathrm{mS} / \mathrm{cm})$ was associated with a germination count of 89, and an EC value of $6.9 \mathrm{mS} / \mathrm{cm}$ was associated with the highest germination count of 121. As shown in Table 4, EC demonstrated a strong negative correlation with GI (LFGI).

EC is a measurement of the level of soluble salts from decomposing manure compounds that are critical for plant growth. EC can indicate the phytotoxicity of the compost through its salinity (Lin, 2008). Studies by Fernández et al. (2007), Tiquia (2005), and Saviozzi et al. (1987) demonstrated a good GI range at EC values of 2.0-3.0 mS/cm, where a GI correlation coefficient of -0.719 was significant at $\mathrm{p}<0.01$.

\section{Chemical analysis of EC and other physiochemical properties of the manure}

Differences and similarities between EC, LFGI, and potential nutrient contents of the samples were observed (Fig. 2). EC demonstrated a non-specific similarity with $\mathrm{pH}$, a positive correlation with $\mathrm{TN}$ and $\mathrm{NH}_{4}-\mathrm{N}$, a partial positive correlation with $\mathrm{K}$, a negative correlation with LFGI and TP, and a partial negative correlation with $\mathrm{NO}_{3}-\mathrm{N}$.

\section{pH, EC, $\mathrm{NaCl}$}

Fig. 2 shows the level of potential nutrient contents of the samples at different maturity stages. For a better outcome, the $\mathrm{pH}$ range should be maintained at 6-9 (Silverstein, 2005; Eklind et al., 2000; Michel et al., 1998). In our study, the average and standard deviation of $\mathrm{pH}$ values were $7.9 \pm 1.1,8.3 \pm 0.5$, and $8.3 \pm 1.5$, with a maximum and minimum value of 8.7 and 4.6 (matured), 9.6 and 6.3 (semi-matured), and 8.9 and 7.6 (immature), respectively (Table 3 ). The $\mathrm{pH}$ conditions observed in these specimens are supported by studies performed by Suresh (2009) and Whalen et al. (2000), which demonstrated that the moderately high $\mathrm{pH}$ of manure can decrease soil acidity for manure application. 


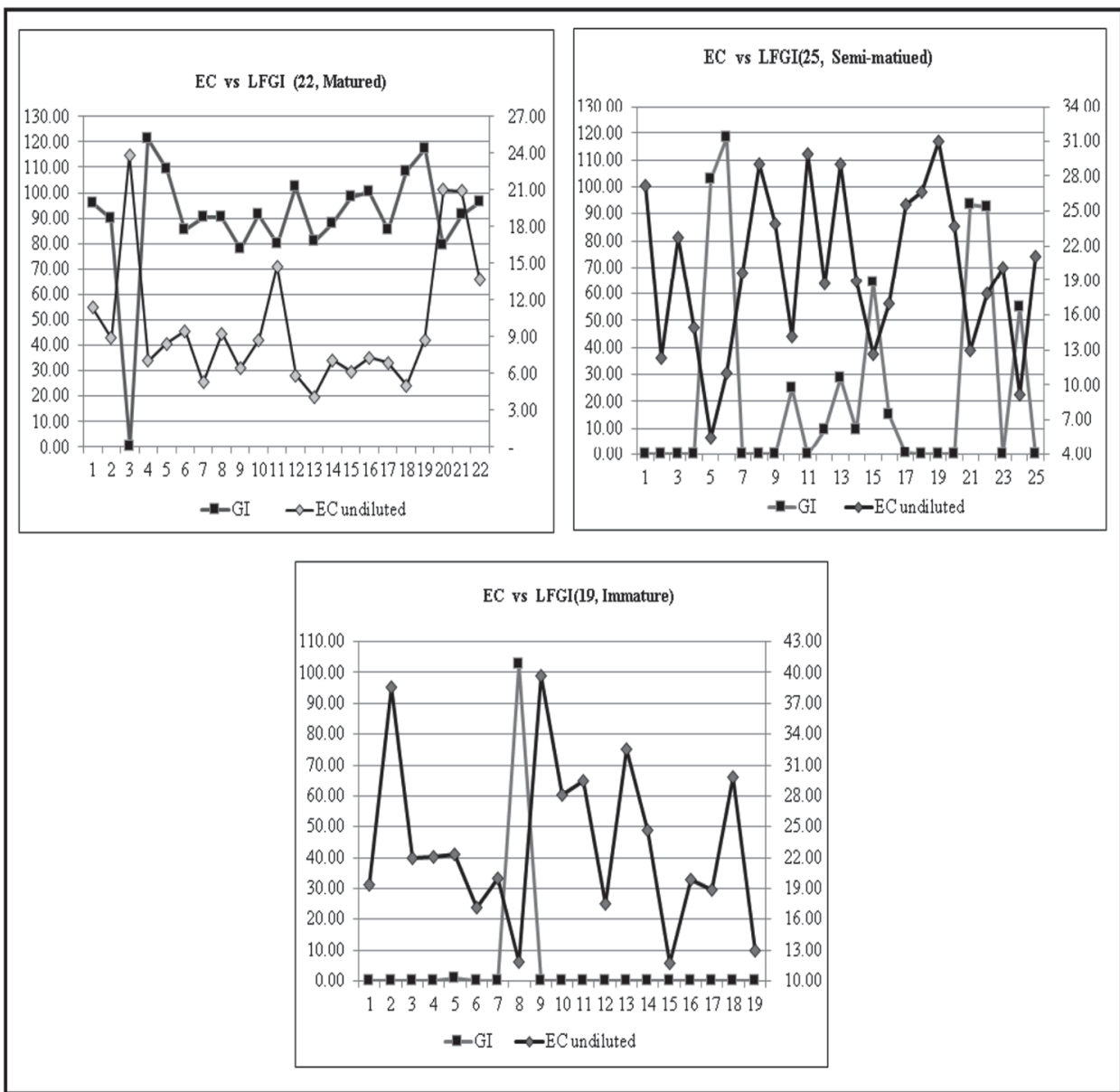

Fig. 1. Relationship (negative correlation) between EC and LFGI at different maturity stages ( matured $=25$; semi-matured $=22 ;$ immature $=19$ ).

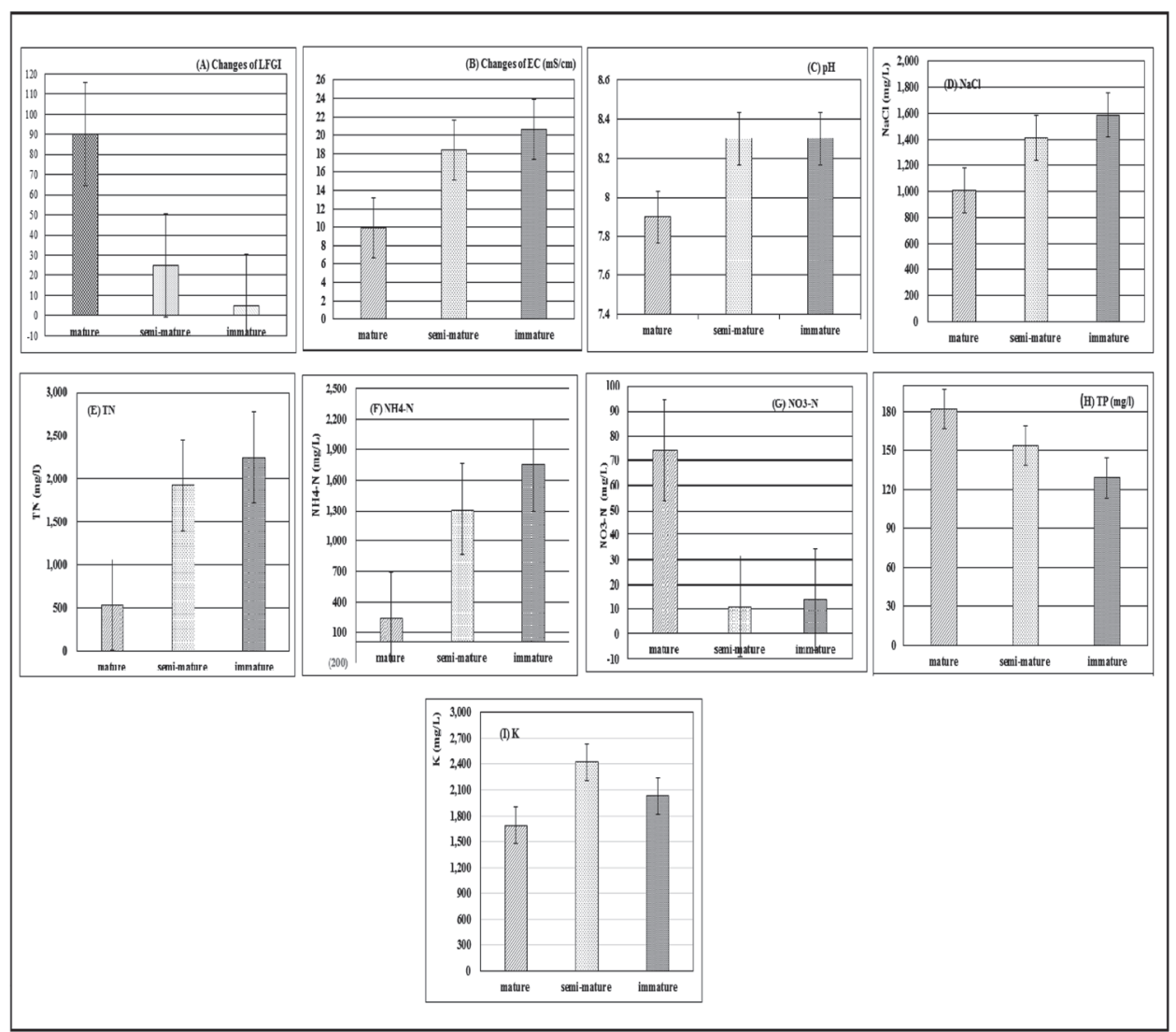

Fig. 2. Differences and similarities between LFGI, EC, $\mathrm{pH}, \mathrm{NaCl}, \mathrm{NH}_{4}-\mathrm{N}, \mathrm{NO}_{3}-\mathrm{N}, \mathrm{TN}$, TP, and $\mathrm{K}$ at different maturity stages. 
On the other hand, average EC values were found to be $9.9 \pm 5.4 \mathrm{mS} / \mathrm{cm}, 18.4 \pm 6.6 \mathrm{mS} / \mathrm{cm}$, and $20.6 \pm 7.3 \mathrm{mS} /$ $\mathrm{cm}$, with a maximum and minimum value of 23.5 and $4.1 \mathrm{mS} / \mathrm{cm}$ (matured), 29.1 and $5.4 \mathrm{mS} / \mathrm{cm}$ (semimatured), and 35.9 and $10.3 \mathrm{mS} / \mathrm{cm}$ (immature), respectively (Table 3 ). These values are comparable to those in studies by Martínez-Suller et al. (2008), Moral et al. (2005), Scotford et al. (1998), and Kirchmann and Witter (1992). Although EC and pH showed a parallel growth pattern in Fig. 2, they did not have any significant relationship with each other (Table 4); this finding is similar to results of other studies (Moral et al., 2005; Scotford et al., 1998; Piccinini and Bortone, 1991; Kirchmann and Witter, 1992). However, $\mathrm{NaCl}$ showed a similar positive growth pattern with EC, having an average concentration of 1,007 $\pm 532.1 \mathrm{mg} / \mathrm{L}$ (matured), 1,411 $\pm 592.7 \mathrm{mg} / \mathrm{L}$ (semi-matured), and 1,587 $\pm 429.3 \mathrm{mg} / \mathrm{L}$ (immature) (Table 3 and Fig. 2).

\section{$\mathbf{T N}, \mathbf{N H}_{4}-\mathbf{N}, \mathbf{N O}_{3}-\mathbf{N}$}

Among the major nutrients of plants, nitrogen is the most difficult to estimate in manure because of its variable forms (Martı́nez-Suller et al., 2008; Moral et al., 2005). Therefore, measurements of $\mathrm{NH}_{4}-\mathrm{N}$ and $\mathrm{NO}_{3}-\mathrm{N}$ are necessary. In Table 3 , the properties of $\mathrm{TN}, \mathrm{NH}_{4}-\mathrm{N}$, and $\mathrm{NO}_{3}-\mathrm{N}$ are shown. TN values were $534 \pm 613.8$, $1,924 \pm 949.6$, and 2,242 \pm 944.3 for matured, semimatured, and immature stages, respectively. The observed trend could be explained by the loss of moisture during oxidation of organic matter (Huang et al., 2004) in the semi-matured and immature specimens. $\mathrm{NH}_{4}-\mathrm{N}$ values were $74 \pm 93.2$ (matured), $11 \pm 7.9$ (semi-matured), and $14 \pm 8.5$ (immature), and $\mathrm{NO}_{3}-\mathrm{N}$ values were $74 \pm 93.2$ (matured), $11 \pm 7.9$ (semi-

Table 3. Physiochemical properties of 66 specimens at different maturity stages

\begin{tabular}{|c|c|c|c|c|}
\hline Properties & & Matured (22) & Semi-matured (25) & Immature (19) \\
\hline \multirow{6}{*}{$\mathrm{pH}$} & Mean $\pm \mathrm{SD}^{*}$ & $7.9 \pm 1.1$ & $8.3 \pm 0.5$ & $8.3 \pm 0.5$ \\
\hline & Max. & 8.7 & 9.0 & 8.9 \\
\hline & Min. & 4.6 & 6.3 & 7.6 \\
\hline & Mean $\pm \mathrm{SD}^{*}$ & $8.3 \pm 1.3$ & $8.7 \pm 0.4$ & $8.7 \pm 0.1$ \\
\hline & Max. & 9.1 & 9.1 & 8.9 \\
\hline & Min. & 4.5 & 6.7 & 8.4 \\
\hline \multirow{6}{*}{$\mathrm{EC}(\mathrm{mS} / \mathrm{cm})$} & Mean $\pm \mathrm{SD}^{*}$ & $9.9 \pm 5.4$ & $18.4 \pm 6.6$ & $20.6 \pm 7.3$ \\
\hline & Max. & 23.5 & 29.1 & 35.9 \\
\hline & Min. & 4.1 & 5.4 & 10.3 \\
\hline & Mean $\pm \mathrm{SD}^{*}$ & $5.1 \pm 2.3$ & $8.6 \pm 2.7$ & $9.3 \pm 2.4$ \\
\hline & Max. & 10.6 & 13.4 & 14.4 \\
\hline & Min. & 2.5 & 3.0 & 5.0 \\
\hline \multirow{3}{*}{$\mathrm{NaCl}(\mathrm{mg} / \mathrm{L})$} & Mean $\pm \mathrm{SD}^{*}$ & $1,007 \pm 532.1$ & $1,411 \pm 592.7$ & $1,587 \pm 429.3$ \\
\hline & Max. & 2,523 & 2,513 & 2,533 \\
\hline & Min. & 387 & 168 & 931 \\
\hline \multirow{3}{*}{$\mathrm{TN}(\mathrm{mg} / \mathrm{L})$} & Mean $\pm \mathrm{SD}^{*}$ & $534 \pm 613.8$ & $1,924 \pm 949.6$ & $2,242 \pm 944.3$ \\
\hline & Max. & 2,942 & 3,397 & 4,277 \\
\hline & Min. & 39 & 280 & 562 \\
\hline \multirow{3}{*}{ NH4-N (mg/L) } & Mean $\pm \mathrm{SD}^{*}$ & $238 \pm 481.9$ & $1,313 \pm 766.5$ & $1,752 \pm 784.3$ \\
\hline & $\operatorname{Max}$ & 2,228 & 2,858 & 3,488 \\
\hline & Min. & 0 & 165 & 392 \\
\hline \multirow{3}{*}{ NO3-N (mg/L) } & Mean $\pm \mathrm{SD}^{*}$ & $74 \pm 93.2$ & $11 \pm 7.9$ & $14 \pm 8.5$ \\
\hline & Max. & 426 & 27 & 36 \\
\hline & Min. & 0 & 0 & 0 \\
\hline \multirow{3}{*}{$\mathrm{TP}(\mathrm{mg} / \mathrm{L})$} & Mean $\pm \mathrm{SD}^{*}$ & $182 \pm 163.6$ & $154 \pm 126.4$ & $129 \pm 107.7$ \\
\hline & Max. & 608 & 634 & 463 \\
\hline & Min. & 19 & 18 & 34 \\
\hline \multirow{3}{*}{$\mathrm{K}(\mathrm{mg} / \mathrm{L})$} & Mean $\pm \mathrm{SD}^{*}$ & $1,691 \pm 857.2$ & $2,425 \pm 746.6$ & $2,034 \pm 779.9$ \\
\hline & Max. & 3,472 & 3,898 & 3,574 \\
\hline & Min. & 88 & 796 & 34 \\
\hline
\end{tabular}


matured), and $14 \pm 8.5$ (immature). According to Hirai (1983), decreasing $\mathrm{NH}_{4}-\mathrm{N}$ level during treatment indicates high quality decomposition; this is illustrated in Fig. 2. In addition, $\mathrm{NH}_{4}-\mathrm{N}$ and $\mathrm{EC}$ showed a parallel growth pattern, whereas $\mathrm{NO}_{3}-\mathrm{N}$ and $\mathrm{EC}$ showed a reverse growth pattern.

\section{TP and $K$}

Phosphorus is one of the main components of the NPK system. This macronutrient plays an important role in regulating plant growth. Table 3 and Fig. 2 show the levels of TP in this study. Average concentrations of TP were $182 \pm 163.6 \mathrm{mg} / \mathrm{L}$ (matured), $154 \pm 126.4 \mathrm{mg} / \mathrm{L}$ (semi-matured), and $129 \pm 107.7 \mathrm{mg} / \mathrm{L}$ (immature), and growth of TP was counter to the growth of EC. In this study (Table 3), average $\mathrm{K}$ concentration values were $1,691 \pm 857.2 \mathrm{mg} / \mathrm{L}$ (matured), 2,425 $\pm 857.2 \mathrm{mg} / \mathrm{L}$ (semi-matured), and 2,034 $\pm 857.2 \mathrm{mg} / \mathrm{L}$ (immature) (Fig. 2), which were not sequential. That may explain why $\mathrm{K}$ had a negative correlation with LFGI; however, changes in $\mathrm{K}$ cation during decomposition demonstrated it had a positive correlation with EC.

\section{Correlation between EC and physiochemical parameters}

The significance levels of the Pearson's correlation coefficients between EC, physiochemical parameters and plant nutrient contents are shown in Table 4 . It should be noted that $\mathrm{pH}$ was previously not correlated with any of the nutrient contents in other studies (Martínez-Suller et al., 2008; Moral et al., 2005). EC could be an effective measurement indicator of ionic species in manures, such as ammonium, nitrate and potassium (Martínez-Suller et al., 2008; Moral et al., 2005). $\mathrm{NH}_{4}^{+}$is a dominant cation that breaks down to $\mathrm{NO}_{3}^{-}$; as a result, EC can have a significant positive correlation with $\mathrm{NH}_{4}-\mathrm{N}$ (Stevens, 1995) and negative correlation with $\mathrm{NO}_{3}-\mathrm{N}$. For the same reason, it can also have a similar correlation pattern with $\mathrm{K}^{+}$; however, EC is not a good indicator of organic parameters such as Org-N and Org-P (Márquez-Molina et al., 2014).

\section{$\mathbf{T N}, \mathbf{N H}_{4}-\mathbf{N}$, Org- $-\mathbf{N}, \mathbf{N O}_{3}-\mathbf{N}$}

There was a significant high positive correlation ( $\mathrm{p}$ $<0.01$ ) between EC and $\mathrm{TN}, \mathrm{NH}_{4}-\mathrm{N}$, and Org-N at $0.879,0.816$, and 0.720 , respectively. On the other hand, $\mathrm{NO}_{3}-\mathrm{N}$ was significant at $\mathrm{p}<0.005$, demonstrating a weak negative correlation with $\mathrm{EC}$ at -0.315 . In Fig. $3(\mathrm{~B}, \mathrm{C}, \mathrm{D}, \mathrm{E})$, the regression equation corresponding to three nitrogen components are shown with their correlation with EC. Here, regression analyses of pig manures were highly significant at $\mathrm{p}<0.01$ for the nitrogen compounds. TN had the highest determination coefficient with $\mathrm{EC}$ at $\mathrm{r}^{2}=0.7718$ [regression equation, $\mathrm{TN}(\mathrm{mg} / \mathrm{L})=$ 124.53 (EC (mS/cm)) - 468.05]. The determination coefficient of $\mathrm{NH}_{4}-\mathrm{N}$ was $\mathrm{r}^{2}=0.6653$ [regression equation, $\left.\mathrm{NH}_{4}-\mathrm{N}(\mathrm{mg} / \mathrm{L})=95837(\mathrm{EC}(\mathrm{mS} / \mathrm{cm}))-473.47\right]$ and Org-N was $\mathrm{r}^{2}=0.5182$ [regression equation, Org-N $(\mathrm{mg} / \mathrm{L})=29.459(\mathrm{EC}(\mathrm{mS} / \mathrm{cm}))-56.61]$. On the other hand, the determination coefficient of $\mathrm{NO}_{3}-\mathrm{N}$ was $\mathrm{r}^{2}=$ 0.1594 [regression equation $\mathrm{NO}_{3}-\mathrm{N}(\mathrm{mg} / \mathrm{L})=-44.941 \mathrm{ln}$ $(\mathrm{EC}(\mathrm{mS} / \mathrm{cm}))+152.21]$. These findings are similar to the results of studies by Suresh (2009), Martínez-Suller et al. (2008), and Moral et al. (2005).

\section{TP}

EC did not have significant correlation with TP (0.289, p < 0.005) (Table 4). The regression equation was TP $(\mathrm{mg} / \mathrm{L})=4.939 \mathrm{EC}(\mathrm{mS} / \mathrm{cm})+76.137$, and the determination coefficient was $\mathrm{r}^{2}=0.5182$ (Fig. 3). $\mathrm{P}$ is associated with manure struvite as a solid fraction. Studies have suggested that P contents are better indicated by solid-related parameters (Moral et al., 2005; Scotford et al., 1998; Stevens et al., 1995; Piccinini and Bortone, 1991). Therefore, estimating $\mathrm{P}$ based on EC may not be accurate (Provolo and Martinez-Suller, 2007).

\section{$\mathbf{K}$}

The correlation between $\mathrm{K}$ and EC was high (0.693, $\mathrm{p}<0.01$ ) (Table 4). K was easily defined by EC; the determination coefficient was $\mathrm{r}^{2}=0.4798$, and the regression equation was $\mathrm{K}(\mathrm{mg} / \mathrm{L})=74.108 \mathrm{EC}(\mathrm{mS} / \mathrm{cm})$

Table 4. Correlation coefficients between major physiochemical properties in matured liquid fertilizer

\begin{tabular}{|c|c|c|c|c|c|c|c|c|c|c|c|}
\hline Properties & $\mathrm{pH}^{1)}$ & $\mathrm{EC}^{1)}$ & $\mathrm{EC}^{2)}$ & $\mathrm{NaC}^{1)}$ & $\mathrm{TN}$ & $\mathrm{NH}_{4}-\mathrm{N}$ & $\mathrm{NO}_{3}-\mathrm{N}$ & Org-N & $\mathrm{P}$ & $\mathrm{K}$ & GI \\
\hline $\mathrm{pH}^{1)}$ & 1 & & & & & & & & & & \\
\hline $\mathrm{EC}^{1)}$ & 0.139 & 1 & & & & & & & & & \\
\hline $\mathrm{EC}^{2)}$ & 0.128 & $0.980^{* *}$ & 1 & & & & & & & & \\
\hline $\mathrm{NaC}^{\mathrm{l})}$ & 0.077 & $0.625^{* *}$ & $0.626^{* *}$ & 1 & & & & & & & \\
\hline $\mathrm{TN}$ & $0.367^{* *}$ & $0.879 * *$ & $0.875^{* *}$ & $0.550 * *$ & 1 & & & & & & \\
\hline $\mathrm{NH}_{4}-\mathrm{N}$ & $0.365^{* *}$ & $0.816^{* *}$ & $0.823 * *$ & $0.517^{* *}$ & $0.961^{* *}$ & 1 & & & & & \\
\hline $\mathrm{NO}_{3}-\mathrm{N}$ & $-0.385^{* *}$ & $-0.315^{*}$ & $-0.327 * *$ & $-0.355^{* *}$ & $-0.292 *$ & $-0.302 *$ & 1 & & & & \\
\hline Org-N & $0.293^{*}$ & $0.720 * *$ & $0.701 * *$ & $0.402 * *$ & $0.737^{* *}$ & $0.550 * *$ & $-0.310^{*}$ & 1 & & & \\
\hline $\mathrm{P}$ & $-0.521^{* *}$ & $0.289 *$ & $0.257^{*}$ & $0.254^{*}$ & 0.186 & 0.137 & 0.040 & 0.216 & 1 & & \\
\hline K & 0.090 & $0.693^{* *}$ & $0.667 * *$ & $0.736 * *$ & $0.567^{* *}$ & $0.459 * *$ & $-0.337 * *$ & $0.613^{* *}$ & $0.435^{* * *}$ & 1 & \\
\hline $\mathrm{GI}^{3)}$ & $-0.393^{* *}$ & $-0.719 * *$ & $-0.724^{* *}$ & $-0.402^{* *}$ & $-0.826 * *$ & $-0.803 * *$ & $0.324 * *$ & $-0.582^{* *}$ & -0.001 & $-0.385 * *$ & 1 \\
\hline
\end{tabular}

*significant at $\mathrm{p}<0.005 ;{ }^{* *}$ significant at $\mathrm{p}<0.01 ;{ }^{1)}$ before LFGI dilution; ${ }^{2)}$ after LFGI dilution; ${ }^{3)}$ LFGI 


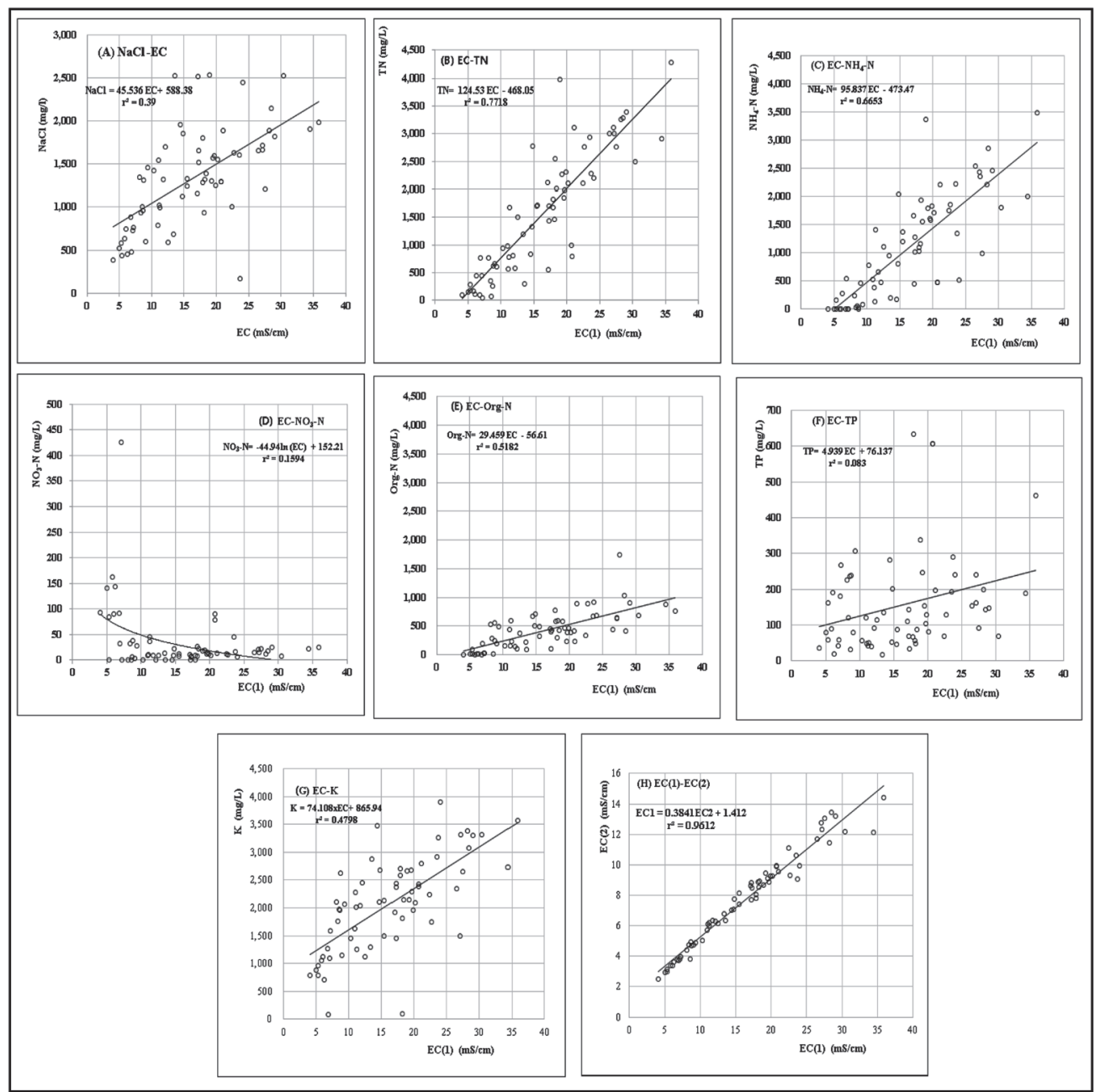

Fig. 3. Correlation between raw electrical conductivity (EC) values of manure samples and other physiochemical properties $\left(\mathrm{NaCl}, \mathrm{TN}, \mathrm{NH}_{4}-\mathrm{N}, \mathrm{NO}_{3}-\mathrm{N}, \mathrm{K}\right.$, and $\mathrm{EC}$ [diluted]).

+ 865.94 (Fig. 3). K has been demonstrated to be highly correlated with EC by Stevens et al. (1995) and Moral et al. (2005). This suggests the feasibility of measuring $\mathrm{K}$ in manure by EC.

\section{$\mathrm{NaCl}$ (salt)}

As mentioned previously, EC values reflect the degree of salinity in manure (Varma and Kalamdhad, 20113); this explains the strong correlation of EC with $\mathrm{NaCl}$ (0.625), which was significant at $\mathrm{p}<0.01$ (Table 4). The determination coefficient was $r^{2}=0.39$, and the regression equation of $\mathrm{NaCl}$ was $\mathrm{NaCl}(\mathrm{mg} / \mathrm{L})=45.536$ $\mathrm{EC}(\mathrm{mg} / \mathrm{L})+588.38$.

\section{CONCLUSION}

Quality measurement of liquid manure is necessary to ensure the effective use of manures and develop new technologies for environmental safety. The physiochemical properties and maturity degree (LFGI) of manure samples were assessed in this study. EC was found to be a suitable indicator of nutrient contents and GI. EC showed a strong positive specific correlation with $\mathrm{TN}$, $\mathrm{NH}_{4}-\mathrm{N}$, Org- $\mathrm{N}$, and $\mathrm{K}$ and a strong negative correlation with GI (LFGI). The efficiency of EC as a quality predic- tion tool has been demonstrated for animal compost and slurry type fertilizers. This study revealed that EC could be used as an indicator in rapid testing methods for quality control based on the correlation of EC with nutrient contents. For improved validation, both LFGI and EC may be used for the same purpose. Furthermore, the EC value for optimal correlation was determined to be between $10.3 \mathrm{mS} / \mathrm{cm}$ and $4.1 \mathrm{mS} / \mathrm{cm}$ (Table 3 ), which is in-between the recommended EC level $(15 \mathrm{mS} / \mathrm{cm})$ of the LFQC certification system. According to previous studies and the present study, EC could be conveniently used as a parameter in rapid testing methods for quality control of any types of liquid manure before use as a fertilizer.

\section{ACKNOWLEDGMENTS}

This research was funded by the Ministry of Agriculture, Food and Rural Affairs (MAFRA) (project \# 316024-3" Livestock Manure Nutrient Management and Business Model"). In particular, we express a very special and sincere thanks to Prof. Yabe, Kyushu University, Japan for his valued collaboration in the experimental design and interpretation of the results of this study and for his help in writing this research paper. 


\section{REFERENCES}

Alburquerque, J.A., J. Gonzálvez and D. García 2006 Measuring detoxification and maturity in compost made from "alperujo", the solid by-product of extracting olive oil by the two-phase centrifugation system. Chemosphere, 64: 470-477

Araji, A.A., Z.O. Abdo and P., Joyce 2001 Efficient use of animal manure on cropland: Economic analysis. Bioresource Technology, 79:179-191

Baloda, S.B., L. Christensen and S. Trajcevska 2001 Persistence of a Salmonella enterica Serovar Typhimurium DT12 clone in a piggery and in agricultural soil amended with Salmonella-contaminated slurry. Applied and Environmental Microbiology, 67: 2859-2862

Butler, T.A., L.J. Sikora, P.M. Steinhilber and L.W. Douglass 2001 Compost age and sample storage effects on maturity indicators of biosolids compost. Journal of Environmental Quality, 30: 2141-2148

Castillón, P., 199. Valoración agronómica de las deyecciones animales. In "Residuos ganaderos. Fundación jornadas técnicas. Fundación "La Caixa”", ed. by S.A Aedos. Barcelona. pp. $131-140$

Chen, K.S., Y.S. Lin and S.S. Yang 2007 Application of Thermotolerant microorganisms for biofertilizer preparation. Journal of Microbiology, Immunology and Infection, 40: 462-473

Eklind, Y. and H. Kirchmann 2000 Composting and storage of organic household waste with different litter amendments. II: nitrogen turnover and losses. Bioresource Technology, $\mathbf{7 4}$ : 125-133

European environmental agency 2000 calculation of nutrient surpluses from agricultural sources. in "technical report 51 istat (2001)". 51 censimento generale dell'agricoltura. <www. istat. it>

Fernández, J.M., D. Hernández, C. Plaza and A. Polo 2007 Organic matter in degraded agricultural soils amended with composted and thermally-dried sewage sludge. Science of the Total Environment, 378: 75-80

Hirai, M.F., V. Chanyasak and H. Kubota 1983 A standard measurement for compost maturity. Biocycle, 24: 54-56

Huang, G.F., J.W.C. Wong, Q.T. We and B.B. Nagar 2004 Effect of $\mathrm{C} / \mathrm{N}$ on composting of pig manure with sawdust. Waste Management, 24: 805-813

Kirchmann, H. and E. Witter 1992 Composition of fresh, aerobic and anaerobic farm animal dungs. Bioresource Technology, 40: $137-142$

Lin, C., 2008. A negative-pressure aeration system for composting food wastes. Bioresource Technology, 99: 7651-7656

Lorimor, J., 2004 Manure characteristics. In "MWPS. Mid-West. Plan Service", Iowa State University. 18: 2-24

Martı́nez-Suller, L., A. Azzellino and G. Provolo 2008 Analysis of livestock slurries from farms across Northern Italy: Relationship between indicators and nutrient content. Biosystems Engineering, 99: 540-552

Michel, F.C. and C.A. Reddy 1998 Effect of oxygenation level on yard trimmings composting rate, odor production, and compost quality in bench-scale reactors. Compost Science and Utilization, 6: $6-14$

Moore, J.E, M. Watabe, A. Stewart, B.C. Millar and J.R. Rao 2009 A novel challenge test incorporating irradiation $((60) \mathrm{co})$ of compost sub-samples to validate thermal lethality towards pathogenic bacteria. Ecotoxicology and Environmental Safety, 72: 144-153

Moral, R., M.D. Perez-Murcia, A. Perez-Espinosa, J. MorenoCaselles and C. Paredes 2005 Estimation of nutrient values of pig slurries in Southeast Spain using easily determined properties. Waste Management, 25: 719-725.

Ndegwa, P.M. and J. Zhu 2003 Sampling procedures for piggery slurry in deep pits for estimation of nutrient content. Biosystems Engineering, 85: 239-248

Oleszczuk, P. 2008 The toxicity of composts from sewage sludges evaluated by the direct contact tests phytotoxkit and ostracodtoxkit. Waste Management, 28: 1645-1653

Piccinini, S. and G. Bortone 1991 The fertilizer value of agricultural manure: Simple rapid methods of assessment. Journal of Agricultural Engineering Research, 49: 197-208

Provolo, G. and L. Martinez-Suller 2007 In situ determination of slurry nutrient content by electrical conductivity. Bioresource Technology, 98: 3235-3242

Saviozzi A., R. Riffaldi and R.L. Minzi 1987 Compost maturity by water extract analysis. In "Compost: Production Quality and Use", ed. by De Bertoldi and M. et al. Elsevier, London, pp. 359-363

Scotford, J.M., T.R. Cumby, R.P. White, O.T. Carton, F. Lorenz, U. Hatterman and G. Provolo 1998 Estimation of the nutrient value of agricultural slurries by measurement of physical and chemical properties. Journal of Agricultural Engineering Research, 71: 291-305

Silverstein, R.M., F.X. Webster and D.J. Kiemle 2005 Spectrometric identification of organic compounds, $7^{\text {th }}$ ed., New York: John Wiley \& Sons, Inc.

Stevens, R.J., C.J. O’Bric and O. T. Carton 1995 Estimating nutrient content of animal slurries using electrical conductivity. Journal of Agricultural Science, 125: 233-238

Suresh, A. H.L. Choi, D.I. Oh and O.K. Moon 2009 Prediction of the nutrients value and biochemical characteristics of swine slurry by measurement of EC - Electrical conductivity. Bioresource Technology, 100: 4683-4689

Tam, N.F.Y. and L.L.P. Vrijmoed 1993 Effects of the inoculum size of a commercial bacterial product and the age of sawdust bedding on pig waste decomposition in a pig-on-litter system. Waste Management, 11: 107-115

Tiquia, S.M. 2005 Microbiological parameters as indicators of compost maturity. Applied Microbiology, 99: 816-828

Varma, S.V. and A.S. Kalamdhad 2013 Composting of municipal solid waste (MSW) mixed with cattle manure. International Journal of Environmental Sciences, 3: 2068-2079

Whalen, J.K., C. Chang, G.W. Clayton and J.P. Carefoot 2000 Cattle manure amendments can increase the $\mathrm{pH}$ of acidic soils. Soil Science Society of American Journal, 64: 962-966

Zaha. C., L. Dumitrescu and I. Manciulea 2013 Correlations between composting conditions and characteristics of compost as biofertilizer. Engineering Sciences, Bulletin of the Transilvania University of Brasov, 6: 51-58

Zhu, J., M. N. Pius and Z.J. Zhang 2003 Settling characteristics of nursery pig manure and nutrient estimation by the hydrometer method. Journal of Environmental Science and Health Part B, 38: 379-390

Zhu, J., M.N. Pius and Z.J. Zhang 2004 Manure sampling procedures and nutrient estimation by the hydrometer method for gestation pigs. Bioresource Technology, 92: 243-250 